\title{
3. Living With Drought in the Irrigated Agriculture of the Ebro Basin (Spain): Structural and Water Management Actions
}

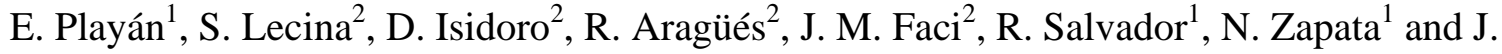 \\ Cavero $^{1}$
}

\subsection{Abstract}

This chapter presents a discussion of a set of technological actions aimed at living with drought in the irrigated agriculture of the Ebro Basin in Spain. The basin faces recurrent drought episodes that have led farmers to take actions on the structural and water management aspects of water conservation. Structural works have taken the form of large irrigation modernization plans, affecting about one-fourth of the currently irrigated land. Modernization typically implies the construction of collective, remote-controlled, pressurized irrigation networks and the installation of on-farm sprinkler/drip irrigation systems. The impacts of these modernization projects on the Ebro Basin hydrology and on the economy and productivity of irrigated agriculture are discussed. In parallel, actions have been set up to improve water management, mostly at the water-user association (WUA) level. The cooperative design, elaboration, and dissemination of a database software supporting daily water management operations in WUAs is presented, and the utilities for drought management are discussed. Finally, a plan for action benefiting from improvements on both structures and water management capacities is presented. This new action comprises automated irrigation scheduling and operation, and is based on a combination of remotely controlled networks, WUA management and meteorological databases, and irrigation engineering tools. The proposed action has already undergone significant research and could result in the generalization of scientific irrigation scheduling and in the complete automation of irrigation operation. Technology can support farmers in their efforts to adapt to drought conditions and still obtain sustainable profits.

\subsection{Introduction}

\footnotetext{
1 Department of Soil and Water, Aula Dei Experimental Station, CSIC. P.O. Box 13034, 50080 Zaragoza, Spain.enrique.playan@eead.csic.es, rsalvador@eead.csic.es, vzapata@eead.csic.es, jcavero@eead.csic.es

${ }^{2}$ Soil and Irrigation Department (associated with CSIC). Agrifood Research and Technology Centre of Aragon (CITA), Aragon Government. Avenida de Montañana 930, 50059 Zaragoza, Spain. lecina@iies.es, disidoro@aragon.es, raragues@aragon.es,jfaci@aragon.es
} 
By the turn of the twentieth century, the government of Spain concluded that the irrigation sector needed to improve its structures and to reduce its water consumption in order to become more competitive and sustainable. At the same time, there was a need to reduce irrigation water use in order to guarantee access to water in the country to all users at all times. In those days, surface irrigation amounted to 59\% of the irrigated area, and $71 \%$ of the area had infrastructure more than 25 years old (MARM 2002). The government of Spain presented a new irrigation policy, the National Irrigation Plan (NIP), promoting the modernization of national irrigation infrastructure (MARM 2002). The plan had two main objectives: 1) to increase the competitiveness of the irrigation sector in order to face the progressive liberalization of agricultural markets and the reduction of subsidies, and 2) to save water $\left(3,000 \mathrm{Mm}^{3} \mathrm{yr}^{-1}\right)$ to alleviate the consequences of cyclical droughts.

Following this policy, irrigation modernization projects have been executed in this decade (2000-2010) on complete Water Users Associations (WUAs). Projects commonly involve replacing surface irrigation systems by pressurized irrigation systems, and constructing on-demand collective, pressurized irrigation networks. The goal was to modernize $2 \mathrm{M}$ ha in a period of 10 years, investing a total of 7,400 $\mathrm{M} €$ (Euro). The government created public companies dedicated to managing NIP investments. These companies organize the farmers' requests for modernization, produce project construction documents, manage subsidies to the WUAs, and control the quality and timing of the construction.

Apparently, during NIP execution the total irrigated area in Spain has not suffered significant changes. In 2007, this area could be estimated as $3.48 \mathrm{M}$ ha (MARM 2007). The most significant change in recent years has been found in the type of irrigation systems, with surface irrigation reducing to $38 \%$ and pressurized irrigation increasing to $62 \%$ of the total irrigated area (MARM 2007). These figures are not representative of the current situation (2010), since the irrigation sector in Spain continues to evolve following the execution of irrigation modernization projects.

The irrigation sector in Spain is exposed to the effects of water scarcity and drought in certain areas. Tió (2000) indicated that 55\% of the irrigated area in Spain had insufficient water allocation. Consequently, the situation is only aggravated by the presence of recurrent droughts. In general, water scarcity is more frequent in the southeastern part of the country, where water resources are more limited in quantity and quality and where irrigation is usually more productive. In a number of Spanish irrigated areas, water scarcity is well documented in the scientific literature. This is the case of Mancha Oriental Aquifer, Murcia or the low Guadalquivir Basin (Martín de Santa Olalla et al. 1999; Custodio 2002). Despite this general trend, drought can appear in any area of Spain, and it often affects WUAs located in the Ebro River Basin, which is the target of this chapter. 
The Ebro Basin, located in northeastern Spain, covers 85,566 km², about $17 \%$ of the national territory (Figure 3.1). This is one of the most intensively irrigated basins in Europe (Wriedt et al. 2009), with about $0.80 \mathrm{M}$ ha of irrigated land (24\% of the total Spanish irrigated land). The irrigation systems in the basin show different typologies. The oldest systems were constructed more than two centuries ago (often many centuries ago), are located in riparian areas, and represent traditional, historical irrigation. A second period of irrigation expansion happened between the eighteenth and twentieth centuries (until the 1960s), when large collective irrigation projects, some of them exceeding $0.1 \mathrm{M}$ ha, were developed. Irrigation technology at the time included canals, open ditches and surface irrigation. Since this was the only available irrigation system, the results were not always satisfactory, with significant project areas showing poor irrigation efficiency (Burt et al. 1997; Playán et al. 2000), and some of them being salt-affected (Herrero and Aragüés 1988). The last period of irrigation expansion began in the 1970s, with the development of sprinkler/drip irrigation, water pressurization and the widespread use of plastic materials in agriculture. These pressurized irrigation projects require periodical technological updates (some of them are more than 30 years old), but show the general benefits of modern irrigation structures.

$<$ Fig. 3.1 $>$

Although the Ebro Valley is diverse in its agriculture, its productive orientation is largely based on field crops. Lecina et al. (2008) presented an analysis of the irrigated area dedicated to types of crops, using data from the period 1996-2002. Their results indicate that field crops occupied 58\%, fruit trees $19 \%$, and olive trees and vineyards $4 \%$ of the total area. Approximately $17 \%$ of the irrigated area was not cropped, due to poor structures, setaside subsidies and the existence of unproductive salt-affected soils (Herrero and Aragüés 1988; Nogués et al. 2000). The orientation to field crops resulted in 70\% of the area being equipped with low-cost surface irrigation systems just before irrigation modernization plans began (Lecina et al. 2008). This percentage is eleven points higher than the national average. Farmers in the Ebro Basin do not have to live with drought every year, but droughts regularly happen, and require adaptations of a different nature.

In this chapter, technological actions aimed at living with drought in the irrigated agriculture of the Ebro Basin in Spain are discussed. Actions are divided into structural and managerial. The effectiveness of actions addressing irrigation structures and water management is discussed, and the synergic effects resulting from the simultaneous use of both approaches are presented.

\subsection{Responses and adaptations: past, present, and future}




\subsubsection{The past: an era of intense water development}

In the past, drought only affected dry-farming agriculture in the Ebro Basin. Irrigation was the final solution for drought, liberating farmers from suffering the economic consequences of crop water stress. These were centuries of water abundance and intense water resources development. Water was always available for new irrigation projects, which were only limited by technical capacity and by the required investments. In the Ebro Basin, water was abstracted from the rivers, constructing large dams and canals. In the twentieth century, the need for hydropower accelerated the construction of reservoirs.

In the last years of the twentieth century, the situation started to change as the construction of irrigation projects progressed (the number of irrigated hectares in the Ebro Basin approached the current figure) and environmental and recreational uses started to count in the water balances. Farmers realized that water was a finite resource. Developing additional water resources became difficult, due to the escalating costs and the social confrontation now accompanying many water resources engineering works.

\subsubsection{The present: two separate approaches}

In the irrigation arena, preparing for drought means increasing technical efficiency (irrigation efficiency), with the goal of obtaining the same agricultural yield or income with less irrigation water. According to Allan $(1997,1999)$ improving technical efficiency would be the last choice, following the use of virtual water and the improvement of economic efficiency. Allan (1999) justified the selection of technical efficiency in that it catalyses other economic sectors (i.e., construction) and does not produce explicit losers. Playán and Mateos (2006) added additional advantages to the improvement of technical efficiency, such as favoring rural development, improving basin-wide water quality, and adding technology to agricultural employments. Two strategies can be followed for improving technical efficiency: improving irrigation structures (irrigation modernization) and improving irrigation management. The following sections describe the actions and analyze the results of both strategies in the Ebro Valley.

\subsubsection{Irrigation modernization}

This section partially presents the results obtained by Lecina et al. (2008), who elaborated on the hydrological consequences of the current irrigation modernization efforts in the Ebro Basin. The NIP will execute modernization projects affecting 175,000 ha until 2009 (plans for further projects have recently been published). This represents $19 \%$ of the irrigated area in the basin, and $27 \%$ of the surface irrigated area before the NIP. In order to analyze the hydrological changes due to modernization, the first step is to determine water consumption before modernization. This is not a trivial task in Spain, since official statistics are published on water use, not on water consumption. Accounting for water use may be a sensible choice in areas where return flows cannot be reused, but leads to significant 
conceptual errors in internal basins. This is the case of the Ebro Basin, where irrigation return flows join the Ebro River and may travel for distances exceeding $200 \mathrm{~km}$ before reaching the Mediterranean Sea. As a consequence, irrigation return flows can be sequentially reused for a number of economic activities, including irrigation.

Molden et al. (1997) presented a water accounting scheme that can be adapted to irrigation water use. According to these authors, the consumptive part of water use is composed of productive evapotranspiration (crop evapotranspiration), non-productive evapotranspiration (evapotranspiration from phreatophytes and weeds, and evaporation from reservoirs, canals and sprinkler irrigation systems), and non-reusable runoff and percolation (flowing to non-exploitable aquifers or to the sea, or non-reusable waters due to water-quality degradation). These concepts were applied by Lecina et al. (2008) to the Ebro Basin, compiling and analyzing information about crops, crop water requirements, hydrology and productivities. A number of works published by the research group on Irrigation, Agronomy and the Environment (EEAD-CSIC and CITA-DGA) as well as other authors, were used for this purpose.

Cropping patterns were obtained for the 1995-96 to 2001-2002 seasons. The results were very different in the areas with surface and pressurized irrigation. In pressurized irrigation, field crops were reduced (from $24 \%$ to $4 \%$ in winter crops, and from $44 \%$ to $25 \%$ in summer crops); whereas, fruit trees increased from $6 \%$ to $30 \%$, and horticultural crops from $3 \%$ to $14 \%$. Land set-aside decreased in pressurized areas, from $18 \%$ to $16 \%$. The availability of pressurized irrigation resulted in a more intense cropping pattern, since pressurized irrigation increases the productive potential of the soils and reduces the production risks.

Table 3.1 presents the results of a hydrologic and economic analysis of the effects of irrigation modernization in the Ebro valley. Crop water requirements were determined using the standard FAO methods (Allen et al., 1998). An average meteorological year was considered in the study. This analysis reflects that basin wide productive evapotranspiration is expected to increase by $6 \%$ with irrigation modernization (from 2,426 to 2,567 $\mathrm{M} \mathrm{m}^{3} \mathrm{yr}^{-}$ ${ }^{1}$ ). A very significant increase (35\%) is expected in the gross value of agricultural production. As a consequence, water productivity expressed as the ratio of the previous variables (Playán and Mateos, 2006) will increase by $27 \%$ (from 0.828 to $1.055 € \mathrm{~m}^{-3}$ ). Under these hypotheses, irrigation productive consumption will increase with irrigation modernization from 17 to $18 \%$ of the average Ebro flow. In terms of the maximum basin storage capacity, modernization will result in a productive consumption increase from 40 to $42 \%$. 
These results were anticipated by Playán and Mateos (2006), who presented three reasons justifying an increase in irrigation productive consumption following modernization. First, an increase in irrigated area without modification of the water rights. Prior to modernization, a number of farms were abandoned due to their poor irrigation structures. After modernization, this land is productive and needs to produce in order to pay back the investment. Second, irrigation modernization increases crop yields due to more uniform irrigation and the possibility of more frequent irrigation (i.e., decreased crop water stress). This increment in yield is generally related to an increase in transpiration. Finally, following modernization, the cropping patterns become more intensive from the points of view of economy and hydrology. These results are not in conflict with the expected increase in on-farm irrigation efficiency following irrigation modernization. This increase can lead from a variable and generally poor efficiency in surface irrigation (40\%-90\%) to a high and uniform efficiency in pressurized irrigation (70\%-90\%). However, these efficiency figures are not relevant in a water balance established in terms of consumptive water use.

These results make it difficult to attain the water-saving benchmarks established by the NIP. In fact, in the Ebro Basin the situation will only get more complicated, with an increase in consumptive use and a corresponding decrease in river flows to the Mediterranean Sea. Irrigation modernization produces a variety of effects on rural societies and the environment. When effects are considered on the Ebro water balance, irrigation modernization will increase water scarcity in the future, if all other variables remain constant.

The reported increase in consumptive use is not the only consequence of irrigation modernization. Table 3.1 presents two very important additional consequences: the increase in the gross value of agricultural production, and the increase in water productivity. Both are very important to ensure the economic sustainability of modern irrigated areas in the basin. The increase in economic water productivity will promote agricultural water uses among other alternative uses in the basin, and will help to maintain the water-agriculture link in the future. One important social benefit of irrigation modernization is the conservation of the irrigated land in the rural areas. Possibly many old traditional surfaceirrigated fields could be abandoned in the near future without the modernization process.

An additional benefit of irrigation modernization is related to the expected decrease in pollutant loads in irrigation return flows. Lecina et al. (2009) analyzed this effect, and concluded that the improvement in on-farm irrigation efficiency and the decrease in conveyance losses will result in a very important decrease in irrigation runoff and percolation losses. As a consequence, soil leaching will be reduced, and the mass of exported fertilizers and other salts will decrease. The generalized adoption of fertigation in pressurized irrigation will lead to a better control of fertilizer application and to a further 
decrease in fertilizer use. As a consequence, irrigation modernization will contribute to reach the objectives of the European Water Framework Directive (European Union 2000), which requires water bodies to reach a "good ecological status" by 2015. Irrigation modernization will decrease the load of salts and fertilizers in the irrigation return flows, and the volume of return flows. At very specific points of the river system (within or near the irrigated area), this will lead to an increase in pollutant concentrations, negatively affecting the direct reuse of these waters for urban, industrial, and agricultural uses. In general, the effect of modernization on water quality will be very positive.

Finally, the modernization of the irrigation systems produce an important effect on rural societies, increasing the technical profile of rural jobs. Farmers and WUA employees will need to increase their labor skills to deal with the elements of pressurized networks and to be able to enjoy the benefits of irrigation controllers and remote surveillance and control systems. Additionally, farmers with pressurized systems will start to use the information on crop water requirements to optimize the irrigation depth. These technologies are an incentive for young professionals to engage in activities that in recent decades were in the hands of aged persons.

The analysis of irrigation modernization has led to positive and negative aspects. The most negative aspect is that modernization will not alleviate pressure on the river. In contrast, water scarcity will increase, and the basin will be one step closer to "closure" (no additional consumptive water uses are possible in the basin) (Seckler et al. 2003). As a consequence, drought will appear more frequently on the basin, although this effect will have a small quantitative importance (the increase in evapotranspiration was estimated as $6 \%$ in the future scenario).

The most significant effect of modernization on drought will be appreciated at the upper parts of the basin. In these areas, irrigation supply directly depends on reservoirs, and there is no physical chance of diverting return flows for irrigation from upstream WUAs. The improvement in irrigation efficiency will be very important in these areas, since the volume of water stored at the reservoir is divided among the irrigated area, and farmers need to make the most of this volume. Playán et al. (2000) presented an analysis of the Almudévar WUA, which is located at the Riegos del Alto Aragón irrigation project. Before modernization, this area had an average application efficiency (Burt et al. 1997) of 54\%, implying that in order to apply the readily soil available water, estimated as $70 \mathrm{~mm}$, a total of $130 \mathrm{~mm}$ had to be applied to the soil. In particular areas of the WUA, application of more than $200 \mathrm{~mm}$ was required to store as little as $40 \mathrm{~mm}$ in the soil (application efficiency of 20\%). In other areas of the WUA, however, surface irrigation attained efficiencies beyond 80\%, and less than $125 \mathrm{~mm}$ was required to apply $100 \mathrm{~mm}$ to the soil. This large spatial variability is very typical of surface-irrigated areas. The abovementioned gross irrigation depths in surface irrigation cannot be reduced, since they are required for 
the irrigation water to advance to the end of the field. The situation can be even more complicated in other WUAs in the basin, where drought-induced restrictions are passed to farmers as a reduction in both allocated water volume and irrigation discharge. Reducing discharge implies an additional problem in surface-irrigated areas, since it results in a further decrease in application efficiency (Playán and Martínez-Cob 1999). In 2010, the Almudévar WUA will start operation, following irrigation modernization. Application efficiency will likely be as high as $80-90 \%$, and the irrigation depth will be fixed by the farmers with no minimum requirement.

Summarizing this section, irrigation modernization will lead to improved river water quality, due to decreased pollutant loads in irrigation return flows, but will not produce net water saving in the basin. Moreover, it will add to the factors leading to basin closure, and it will increase the frequency of droughts. Modernization will increase crop evapotranspiration and, therefore, aggravate the effects of meteorological droughts. However, the improvement of irrigation efficiency following modernization will result in a clear opportunity to sustain agricultural production in some WUAs during drought periods.

\subsubsection{Irrigation management: the Ador software}

The efforts to improve irrigation management in the Ebro Basin have so far run in parallel to the structural actions. Water management has received limited attention on the part of public administration, although it requires very moderate investments, as compared to structural actions. As a consequence, irrigation management can be more effective in terms of water conservation and drought management than irrigation modernization. There are two additional advantages to irrigation management that are significant in this discussion. First, the improvement in irrigation management is a bottom-up approach: it is generated at the lowest level of water management, and it impregnates all decision-making levels as it proceeds to the organizational top. Second, it produces institutional strengthening at the WUA level. The role of the WUA personnel gains in relevance as they improve their management level and they use better information.

Several authors have stressed the importance of improving the service quality of WUAs. Clemmens and Freeman (1987) reported that WUAs influence the performance of an irrigation project, noting the relevance of a bidirectional information flow between the WUA and its farmers. A few research efforts have been reported in the past on WUA databases (Merkley 1999; Sagardoy et al. 1999; Mateos et al. 2002). In the following paragraphs, a software for WUA management will be presented, focusing on the utilities for irrigation water control under drought periods. The software is named Ador, and the principal design criterion was to enforce adaptability to the different types of irrigation water management performed in the traditional and modern WUAs in Spain. The 
application of the software to the specific case of the Riegos del Alto Aragón irrigation project will be discussed.

The Ador software was presented by Playán et al. (2007) as a contribution to the daily management of WUAs. Software development began in 1998, with the Irrigation, Agronomy and the Environment research group (EEAD-CSIC and CITA-DGA) obtaining research grants from the National Research and Development Plan of the government of Spain and the FEDER funds of the European Union. Software implementation enjoyed additional funds from WUAs, particularly within the Riegos del Alto Aragón project, and the government of Aragón. The irrigation extension office of the government of Aragón (Oficina del Regante) committed funds to software development and implementation, which started in 2001. A number of consulting and engineering firms contributed to these activities. Recently, Ador version 2.0 has been released, co-sponsored by a public company of the government of Aragón.

Ador has three components: a comprehensive database structure, a diagram of the water distribution network, and a GIS module. Technically, Ador is a Microsoft Access ${ }^{\text {TM }}$ application composed of 118 interconnected tables. Ador is being developed in the Spanish language. The last software version, along with the users' manual produced by the Oficina del Regante can be freely downloaded from http://www.eead.csic.es/ador.

A water user is any person or company playing a role in the WUA. This role may be classified in any water use category, such as agricultural, animal farming, industrial, and urban. A water user can be a landowner, a grower or an enterprise. Water users perform their activities in cadastral plots. Each plot is identified by a unique alphanumeric code. Farms are often divided into several cadastral plots. A cadastral plot can be the physical basis of several water uses of different categories (two crops, one animal farm, an alfalfa processing factory, and the farmer's residence).

The irrigation distribution and drainage networks are addressed using a diagram that the WUA manager can modify and extend. Primary network elements include canals, pipes, reservoirs, pumping stations, and water meters. Longitudinal primary elements (pipelines and open channels) can contain secondary elements (hydrants, checks, siphons, valves, airrelease devices, and manometers). Figure 3.2 presents part of the diagram of a WUA using both open-channel and pressurized elements. Each water use is related to two users: 1) the user paying for water; and 2) the user paying the fixed costs. For each agricultural water use, the database can store the crop grown and a detailed description of the on-farm irrigation system. Figure 3.3 describes the linking of primary elements, hydrants, cadastral plots, and water uses.

$<$ Fig. 3.2>

$<$ Fig. 3.3> 
Water distribution can be performed in a WUA following a number of different delivery schedules (Clemmens 1987; Clemmens and Freeman 1987). Ador has been designed to accommodate the delivery schedules typical in the Ebro Basin: on-demand irrigation with volumetric water meters; arranged irrigation, based on prepaid water; arranged irrigation, based on previous water orders; and rotation irrigation. Water prices are described in Ador using a two-dimensional matrix, including the type of water and the category of water use. Different water types can be established in a WUA to reflect differences in water quality, origin, or energy input. Fixed and variable costs are considered separately during the billing process.

Many WUA managers consider the water bill as the main goal and the end of their activity. In Ador, the bill is the starting point to promote the improvement of irrigation water management. This is possible if the bill provides additional information. The Ador water bill informs the farmer of his individual water use, but also includes statistics about water consumption in the WUA. The contrast between water use in a certain plot, crop water requirements, and the average water use in the WUA by crop, irrigation system, and soil type helps the farmer to evaluate his level of irrigation water management.

Geographic Information System (GIS) coverages of the cadastral plots and irrigation network can be used to display the database cartographically. WUAs must adapt the official GIS cadastral coverages by selecting plots belonging to the WUA, and must produce an irrigation network coverage.

Measures can be adopted in Ador to manage scarce water during drought periods. The software incorporates a tool to establish water demand limitations fixed at a certain allocation threshold expressed in units of $\mathrm{m}^{3} \mathrm{ha}^{-1}$. A report is produced listing agricultural water users and their current level of water use. The report is ordered by water use, separating the users exceeding the allocation threshold, those who are close to the threshold and, finally, those who have used a limited amount of water. The report is then used to guide further water allocation in the WUA. Figure 3.4 presents the dialog box used to establish water demand limitations.

$<$ Fig. 3.4>

Ador is currently being used in some 70 WUAs, accounting for more than 175,000 ha in the central Ebro Valley. These WUAs cover a wide range of irrigation technologies and water delivery schedules. Software dissemination started at the Riegos del Alto Aragón Project, which includes 53 WUAs and 124,000 ha in the provinces of Huesca and Zaragoza. The project also supplies urban water to more than 100,000 persons, and to 
several industrial factories and animal farms. In 2001, this project decided to make Ador its standard water management software, with the following objectives: 1) To implement Ador progressively in their WUAs; and 2) to develop a specific data centralization unit at the main project office. Since its onset, the project has been managed by a multidisciplinary steering board. The discussions held in the steering board, and the bi-directional communication with WUA managers have made Ador a widely participative project.

In recent years drought has been a common trait in the Ebro Valley, and it has severely affected Riegos del Alto Aragón (among other irrigation projects). Farmers in this project specializing in field crops have seen water allocation restricted in a number of recent years. Due to strong restrictions, farmers have had to concentrate the available water on part of their farming land. This situation has been particularly difficult in areas characterized by low application efficiency. In other years, prospects have been quite hard at the beginning of the season, but later periods of precipitation have resulted in eased restrictions along the season. In this surface water project, restrictions are very variable in time.

The irrigation project's steering board decides the seasonal volume of water allocation in their meetings. Every time a modification in water allocation is agreed upon, all WUAs need to adapt to the new situation. In practice, this means obtaining a new report using the dialog box in Figure 3.4. These reports are published and communicated to farmers, who can then modify their cropping and irrigation plans accordingly.

A number of farmers' strategies have been identified in these water-restricted years. Some farmers have decided to plant all their land to barley, an early harvesting, low-water use, and drought-resistant crop. In the worst-case scenario, barley can be harvested in June, and that puts an end to the season. If the situation improves during spring, a second crop of corn or sunflower can be established. This double-cropping scheme is greatly favored by irrigation modernization (sprinkler irrigation) and by direct-sowing machines. These technologies are required to quickly plant the second crop and, therefore, take advantage of the warm, sunny July days. Other farmers grow alfalfa with the intention of applying irrigation depths lower than required. Alfalfa shows a linear relationship between irrigation and yield. Being a multi-annual crop, alfalfa has the additional advantage that it survives severe droughts.

\subsubsection{Modernization and management: exploiting synergies}

The differences in irrigation technology have resulted in very different farm approaches to drought. Surface-irrigation farmers using border or basin irrigation in Riegos del Alto Aragón often need between 1,000 and 2,000 $\mathrm{m}^{3} \mathrm{ha}^{-1}$ to complete the first irrigation of the season, since this first irrigation is usually made in a recently plowed field and therefore high infiltration and low water advance occur. In a drought season, this volume of water 
represents a significant part of the seasonal allocation (from 3,000 to 5,000 $\mathrm{m}^{3} \mathrm{ha}^{-1}$ ). As a consequence, these surface irrigation farmers usually plant barley or wheat, if drought can be anticipated at sowing time. Sprinkler irrigation farmers are free to decide the irrigation depth, and can adapt better to drought situations and to changes in meteorology. This flexibility that characterizes modern irrigation systems is very important to protect farm income in drought years. Synergic effects can be exploited by farmers making use of modern irrigation structures and elaborate water-management procedures.

\subsection{The future: water management}

In the previous section, several important advantages of water management have been highlighted, relating to cost effectiveness and institutional growth. Unfortunately, there is an important limitation to water management: it relies on the human factor, and its implementation progresses at the speed of change in human resources. Human resource processes are typically much slower than irrigation modernization. As a consequence, it is easy to foresee that by the time irrigation modernization has made a significant progress in the Ebro Basin, irrigation management will still require significant attention from the individual farmers to the boards governing irrigation projects. This is why in the decades to come, efforts will have to focus on water management.

Water restrictions will continue or increase in the future, incremented by irrigation modernization and fostered by competitive water uses, including environmental and recreational uses. As a consequence, in order to maintain a level of economic performance under drought conditions, farmers will need to better adjust water applications to crop water requirements. At present, significant possibilities for improving irrigation performance can be observed. As an example, Figure 3.5 presents a scatter plot of net seasonal irrigation requirements vs. irrigation water application in agricultural fields throughout the Ebro Basin. These observations were compiled by Martínez-Cob et al. (2005), and contain data from different locations in the basin, a wide variety of crops and all types of irrigation technologies. These data confirm that there is a very large variability in the way farmers respond to crop water requirements. This variability does not only depend on the farmer, since it is very often related to the managerial rules characterizing the WUA. For cases in which irrigation application is lower than crop water requirements, structural water scarcity, drought events or regulated deficit irrigation can be relevant factors determining farmers' behavior.

As modern irrigation structures are installed, and on-demand irrigation is made possible, farmers will become more and more responsible for irrigation decision making. Training farmers and WUA personnel in water management skills will become very 
important to overcome drought periods. The information provided by the Ador software can provide farmers with valuable feedback on how to improve water use in their crops.

A parallel approach consists of the automation of irrigation scheduling and execution, a technique that is now technically possible since:

1. A network of automated agrometeorological stations has been installed in all the irrigated areas of Spain. The SIAR network, installed by the government of Spain in cooperation with the regional governments, publishes daily crop water requirements for hundreds of stations on the Internet.

2. Irrigation modernization projects include a remote-control/supervision module. This module permits operation of all the valves in a collective pressurized network from a central computer.

3. WUA management databases - such as Ador - are now installed in most WUAs. These databases contain information on farmers, plots, crops, structures and irrigation events.

The connection of these three elements permits to a vision in the near future in which a computer determines crop water requirements and applies them to the different farms via the remote control system. Zapata et al. (2009) presented successful simulation results of the application of such a system in a WUA belonging to the Riegos del Alto Aragón project.

During the 2009 irrigation season, an experiment was performed at the EEAD-CSIC experimental farm, in which an automatic scheduling system was applied to the irrigation of a corn crop following a statistical experimental design. The experiment compared two irrigation treatments: a farmer following the weekly information produced by the SIAR network, and the automatic scheduling system. Corn yield was statistically indistinguishable, with yields of 16,262 and 15,645 $\mathrm{kg} \mathrm{ha}^{-1}$ for the farmer and automatic treatments, respectively. While the farmer applied $8,623 \mathrm{~m}^{3} \mathrm{ha}^{-1}$, the automatic system applied $7,036 \mathrm{~m}^{3} \mathrm{ha}^{-1}$. This experiment proves that automatic scheduling can result in water management as good as, or better than, the best farmer. This is very important at a time when many farmers are part-timers, and when best management practices are required to overcome drought periods. A centralized water management scheme must combine intelligent on-farm decision making with optimum management and flexible operation at the WUA, so that farmers can easily introduce their priorities in irrigation scheduling. The water management expertise contained in the current crop water simulation models, such as in the recently released AquaCrop (Steduto et al. 2009), can be very useful to these centralized systems in order to optimize water application under drought.

\subsection{Conclusions and recommendations}


The irrigation modernization projects currently under development in the Ebro Basin will result in social, economic, and environmental advantages. When it comes to evaluating the effect on watershed hydrology, it seems clear that evapotranspiration will increase if the rest of the variables remain constant. This is an important point, since an in-depth analysis of the effects of irrigation modernization should include aspects such as: 1) the sustainability of the traditional WUAs not involved in modernization projects; 2) the acreage of new sprinkler irrigation systems; 3 ) the future prices for crops, water and energy; 4) the economic and population growth. If basin evapotranspiration increases, modernization will contribute to water scarcity and watershed closure, and drought events will increase their frequency and intensity. Irrigation modernization will however contribute to drought management at farm scale, particularly at the upper areas of the basin where water is provided directly from reservoirs. Improving application efficiency will help to protect farm income under severe water restrictions. The benefit/cost ratio will always be lower for irrigation modernization projects than for irrigation management. The advantages of cooperative programs for management improvement go well beyond irrigation efficiency, and include endogenous, participative, and multidisciplinary progress. The case of the Ador software, with a history of more than 10 years of co-evolution between water users, water managers, researchers and consultants, illustrates this process. The transparency that Ador has introduced in water management activities has permitted conflict-free operation during drought years. The future will bring more activities in the field of management, and less structural changes. Further research will be needed to develop management tools that take advantage of the different technologies currently available for irrigation operation. Among them, the complete automation of irrigation scheduling and operation stands as a promising line of work. The irrigation modernization projects in place in Spain have required very heavy investments on the part of the farmers and the government. Today, the cost of a typical irrigation modernization project is similar to the price of the land. Such investments cannot be performed in many agricultural areas of the world. As a consequence, irrigation modernization will in many places be a step-by-step process that will have to wait for higher prices of agricultural commodities. In contrast, the prospects for the generalization of efforts in irrigation management are much better, since the costs are orders of magnitude lower.

\subsection{References}

Allan, T. (1997). Virtual water: a long-term solution for water-short Middle East economies? British Association Festival of Science. In: Water and development session, University of Leeds, United Kingdom.

Allan, T. (1999). Productive efficiency and allocative efficiency: why better management may not solve the problem. Agricultural Water Management 40, 71-75. 
Allen, R.G., Pereira, L.S., Raes, D. \& Smith, M. (1998). Crop evapotranspiration: guidelines for computing crop water requirements. FAO irrigation and drainage paper 56, Rome, Italy. 300 pp.

Burt, C.M., Clemmens, A.J., Strelkoff, T.S., Solomon, K.H., Bliesner, R.D., Hardy, L.A., Howell, T.A. \& Eisenhauer, D.E. (1997). Irrigation performance measures: Efficiency and uniformity. Journal of Irrigation and Drainage Engineering, 123(6), 423-442.

Clemmens, A.J. (1987). Arranged delivery schedules. In: Planning, operation, rehabilitation and automation of irrigation water delivery systems. Proceedings of the Irrigation Division, ASCE. Portland, OR, USA, pp 57-80.

Clemmens, A.J. \& Freeman, D.M. (1987). Structuring distribution agencies for irrigation water delivery. In: Planning, operation, rehabilitation and automation of irrigation water delivery systems. Proceedings of the Irrigation Division, ASCE. Portland, Oregon, pp. 72-80 pp.

Custodio, E. (2002). Aquifer overexploitation: what does it mean? Hydrogeology Journal, 10(2), 254-277.

European Union. (2000). Directive 2000/60/EC of the European Parliament and of the Council establishing a framework for the community action in the field of water policy, Official Journal, L327, 22/12/2000.

Herrero, J. \& Aragüés, R. (1988). Suelos afectados por salinidad en Aragón. Surcos de Aragón, 9.

Lecina, S., Aragüés, R., Playán, E. \& Isidoro, D. (2008). Modernización de regadíos en la cuenca del Ebro: efectos sobre la cantidad y la calidad del agua. Agrifood Research and Technology Centre of Aragon (CITA), Aragon Government. Unpublished report. Zaragoza, Spain. 158 pp.

Lecina, S., Isidoro, D., Playán, E. \& Aragüés, R. (2009). Efecto de la modernización de regadíos sobre la cantidad y la calidad de las aguas: la cuenca del Ebro como caso de estudio. Monografías INIA. Serie agrícola. Número 26. INIA, Madrid, Spain. 92 pp.

MARM (2002). Plan Nacional de Regadíos. Ministerio de Medio Ambiente, Medio Rural y Marino. Madrid, Spain.

MARM (2007). Encuesta sobre superficies y rendimientos de cultivos, Informe sobre regadíos en España. Ministerio de Medio Ambiente, Medio Rural y Marino. Madrid, Spain. 
Martín de Santa Olalla, F., Brasa, A., Fabeiro, C., Fernandez, D. \& López, H. (1999). Improvement of irrigation management towards the sustainable use of groundwater in Castilla-La Mancha, Spain. Agricultural Water Management, 40(2-3), 195-205.

Martínez-Cob, A., Playán, E., Cavero, J. \& García-Vera, M.A. (2005). Recopilación de suministros en cultivos eficientes de la cuenca del Ebro y comparación con las dotaciones objetivo. Internal Report 2005-PH-21.I. Confederación Hidrográfica del Ebro, Zaragoza, Spain.

Mateos, L., López-Cortijo, I. \& Sagardoy, J.A. (2002). SIMIS: the FAO decision support system for irrigation scheme management. Agricultural Water Management, 56(3):193-206.

Merkley, G.P. (1999). Waters. Irrigation Engineering Software Division. Biological and Irrigation Engineering Department, Utah State University. Logan, Utah, USA.

Molden, D.J. (1997). Accounting for water use and productivity. SWIM Paper 1. IWMI. Colombo, Sri Lanka. 16 pp.

Nogués, J., Herrero, J., Rodríguez-Ochoa, R. \& Boixadera, J. (2000). Land evaluation in a salt-affected irrigated district using an index of productive potential. Environmental Management, 25(2), 143-152.

Playán, E. and Martínez-Cob, A. (1999). Simulation of basin irrigation scheduling as a function of discharge and levelling. Investigación Agraria: Producción y Protección Vegetal, 14(3):545-554.

Playán, E., Slatni, A., Castillo, R. \& Faci, J.M. (2000). A case study for irrigation modernisation: II. Scenario Analysis. Agricultural Water Management, 42(2000), 335-354.

Playán, E. \& Mateos, L. (2006). Modernization and optimization of irrigation systems to increase water productivity, Agricultural Water Management, 80, pp. 100-116.

Playán, E., Cavero, J., Mantero, I., Salvador, R., Lecina, S., Faci, J. M., Andrés, J., Salvador, V., Cardeña, G., Ramón, S., Lacueva, J. L., Tejero, M., Ferri, J. \& Martínez-Cob, A. (2007). A database program for enhancing irrigation district management in the Ebro Valley (Spain). Agricultural Water Management, 87(2), 209-216.

Sagardoy, J.A., Pastore, G., Yamashita, I. \& Lopez-Cortijo, I. (1999). SIMIS: scheme irrigation management information system. FAO. Rome, Italy.

Seckler, D., Molden, D. \& Sakthivadivel, R. (2003). The concept of efficiency in waterresources management and policy. In: Water productivity in agriculture: limits and 
opportunities for improvement (Eds. L. W. Kijne, Barker, R., Molden, D.). CAB International 2003. pp. 37-51.

Steduto P., Hsiao, T.C., Raes, D. \& Fereres, E. (2009). AquaCrop - The FAO crop model to simulate yield response to water: I. Concepts and underlying principles. Agronomy Journal, 101: 426-437.

Tió, C. (2000). Futuro de los regadíos y sus posibilidades de expansión. Vida rural, Febrero, 25-28.

Wriedt, G., Van der Velde, M., Aloe, A. \& Bouraoui, F. (2009). Estimating irrigation water requirements in Europe. Journal of Hydrology 373(3-4), 527-544.

Zapata, N., Playán, E., Skhiri, A. \& Burguete, J. (2009). A collective solid-set sprinkler irrigation controller for optimum water productivity. Journal of Irrigation and Drainage Engineering, ASCE, 135 (1): 13-24. 


\section{Tables and figures}

Table 3.1. Characterization of pre- and post-modernization scenarios in the irrigated land of the Ebro Basin, considering the modernization investments 2002-2009 in the National Irrigation Plan and an average meteorological year. Adapted from Lecina et al. (2008).

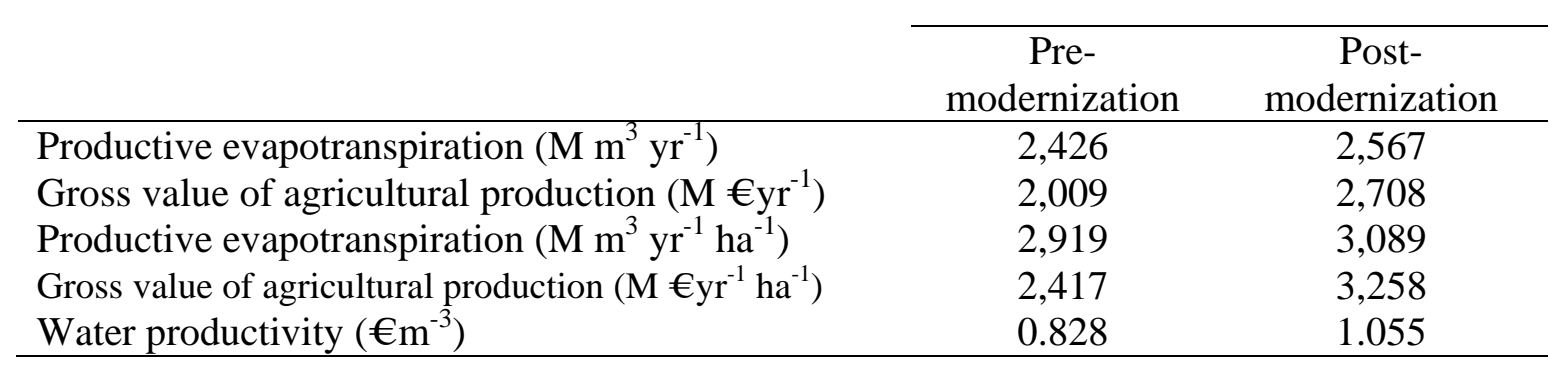


Figure 3.1. Location of the Ebro Basin within the Iberian peninsula.

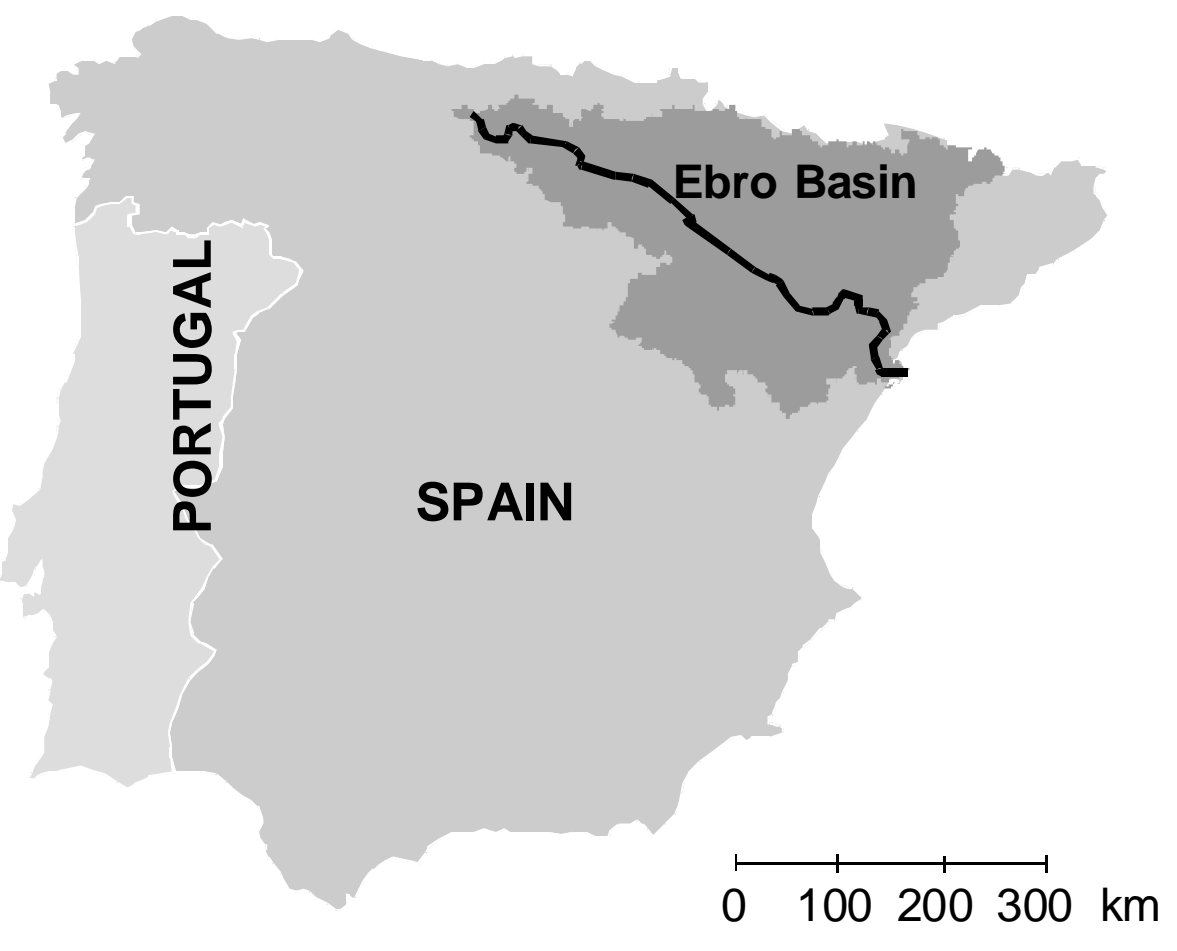


Figure 3.2 Diagram of the primary elements of an irrigation network in the Ador software. Water flows from the icon representing the water source diversion to a branching canal network. The figure also presents the toolbox used to build and manage the diagram.

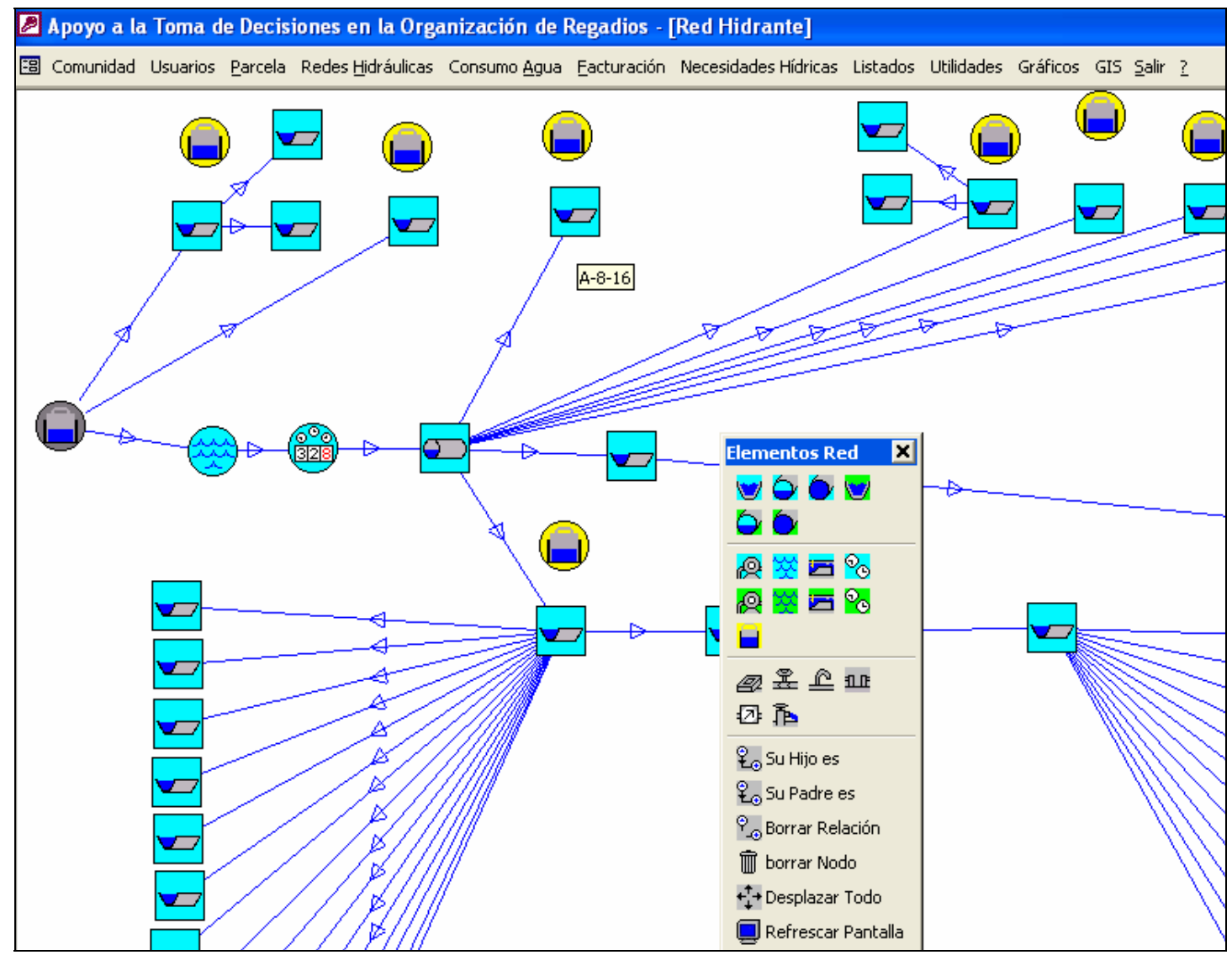


Figure 3.3 Example of the detail offered by the diagram about a primary element of the irrigation water distribution network in the Ador software.

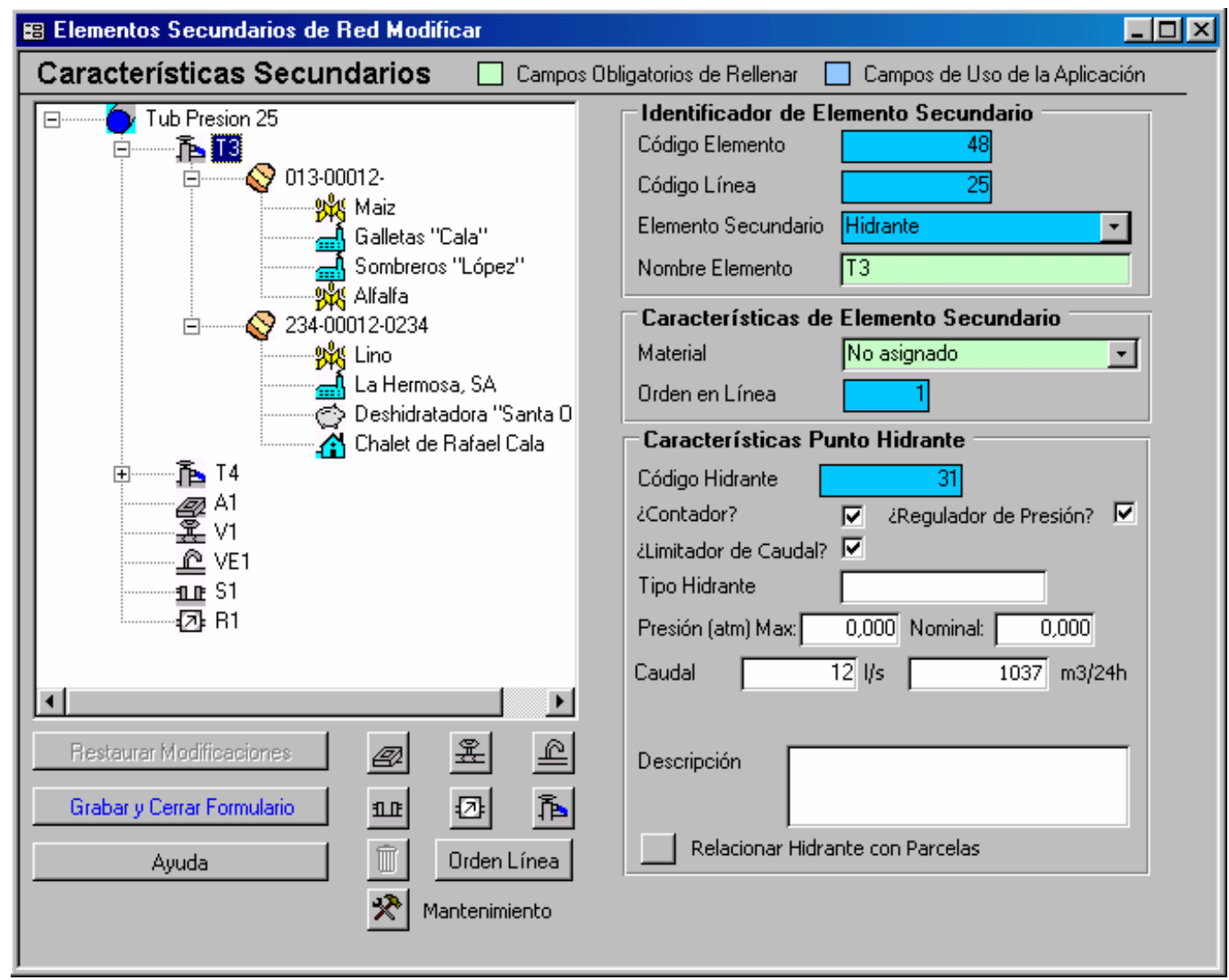


Figure 3.4 Ador dialogue box for the establishment of a limitation of 4,000 $\mathrm{m}^{3} \mathrm{ha}^{-1}$ following a drought event. A report is produced indicating the users who have reached the limitation, the users within $20 \%$ of the limitation and the rest of the users.

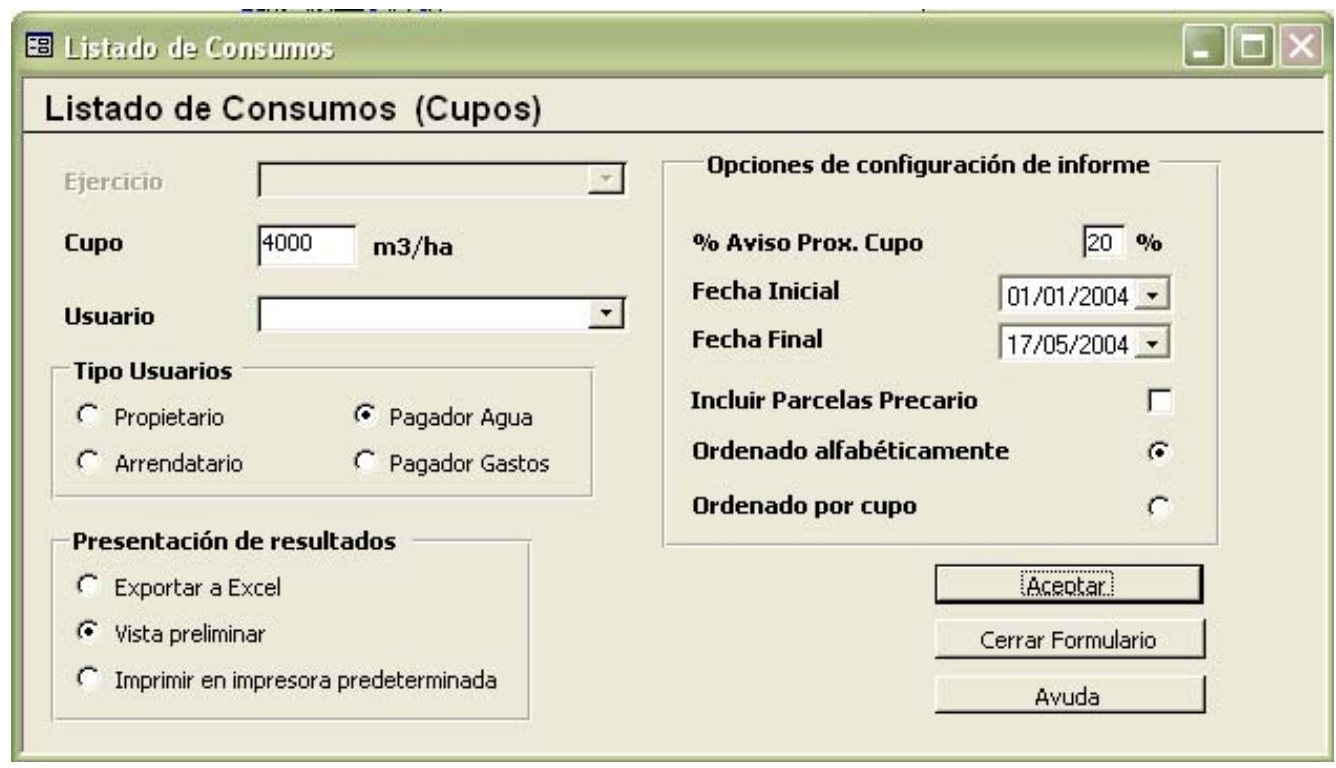


Figure 3.5 Scatter plot of seasonal net irrigation requirements vs. irrigation depth application in the Ebro basin. Adapted from Martínez-Cob et al. (2005).

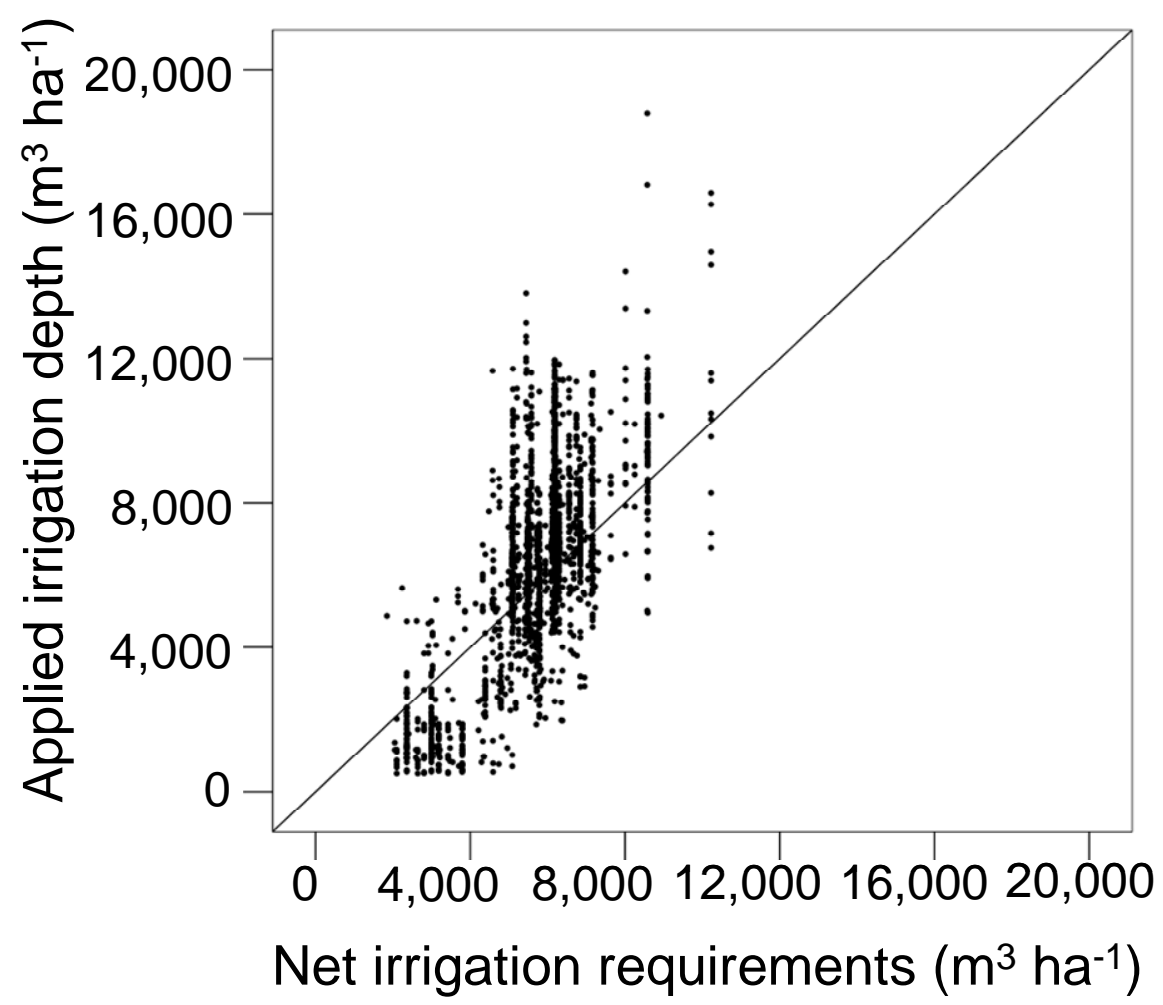

